\title{
A remarkable foraminiferal assemblage from the Quaternary of northeast Greenland
}

\author{
ROLF W. FEYLING-HANSSEN
}

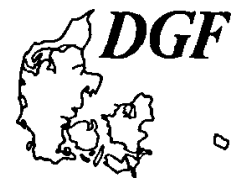

\begin{abstract}
Feyling-Hanssen, R. W.: A remarkable foraminiferal assemblage from the Quaternary of northeast Greenland. Bull. geol. Soc. Denmark, vol. 38, pp. 101-107. Copenhagen, April 25th, 1990. https://doi.org/10.37570/bgsd-1990-38-10

A fossil foraminiferal assemblage with abundant Islandiella inflata (Gudina) from the Ymer Formation in northeasternmost Greenland is described and compared with similar occurrences in Siberia and in Baffin Island. Some of these occurrences seem to be of Holsteinian (Yarmouthian) age.
\end{abstract}

R. W. Feyling-Hanssen, Geological Institute, University of Aarhus, DK-8000. October 10th, 1989.

Near Nordostrundingen in northeasternmost Greenland, at a locality called Kilen, at $81^{\circ} 10^{\prime}$ north latitude (Fig. 1), C. Hjort of Lund University, Sweden, investigated sedimentary outcrops, and established the Ymer Formation. This is a $6-10 \mathrm{~m}$ thick sequence, with a rich fossil content of foraminifera, molluscs and cirripeds, reflecting interglacial climatic conditions. Absolute age determination by radiocarbon gave a minimum of 40,300 years before present, Uranium/Thorium gave 103,000 years B.P., thermoluminescence method gave 190,000-220,000 B.P., and amino-acid-derived estimates were 220,000-270,000 B.P. The Ymer Formation is, therefore, probably of Holsteinian (Yarmouthian) age (Hjort, 1981; Hjort and Feyling-Hanssen, 1987).

Two sediment samples from the Ymer Formation, collected by Hjort, were investigated for their content of fossil foraminifera. The faunas were briefly dealt with in a paper by Hjort and Feyling-Hanssen (1987), but the remarkably abundant occurrence of the species Islandiella inflata (Gudina) justifies a closer account of the matter. Islandiella inflata - in abundance - may well turn out to be an Upper Mid-Pleistocene marker in the Arctic.

One of the samples, CHT 8, was taken $7 \mathrm{~m}$ above present-day sea level from stratified sand with many dropstones, the other, CHT 13, at $8 \mathrm{~m}$ a.s.l. from horizontally stratified, well sorted medium sand.

Both samples contained fossil benthonic foraminifera, 1,900 specimens/100 g sediment in sam- ple CHT 8, 2,400/100 g in sample CHT 13. Preservation was mainly poor, a number of specimens had later chambers broken off and most had corroded test surfaces, particularly those from sample CHT 13. Acidic ground-water percolating through the sandy sediments may have affected the calcium carbonate tests of the foraminifera. In this respect it is interesting to note that many coal and lignite particles occurred in the samples, particularly CHT 13. However, identification of the specimens was not impeeded by this corrosion (cf. Plates 1-3).

The assemblages are both of Quaternary age, but differ in composition. This was most probably caused by difference in water depth during deposition, rather than by any considerable difference in age.

\section{The Islandiella inflata assemblage of sample CHT 8}

The sample was processed and examined in the standardized way (Feyling-Hanssen, 1983). The results of the analysis are presented in Table 1.

The characteristic feature of this sample is the high frequency of the conspicuous and quite large species Islandiella inflata (Gudina), which accounts for $32 \%$ of the counted fauna. Three specimens of this species from sample CHT 8 are illustrated on plate 1 , figs $8-14$. Figs $8-10$ show three views of a megalospheric specimen, 11-14 


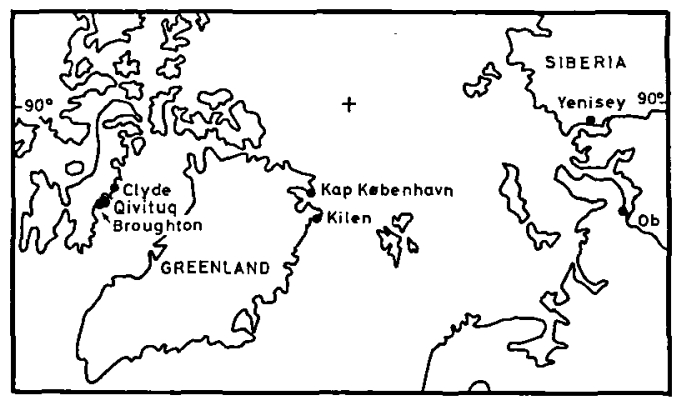

Fig. 1. Some of the localities mentioned in the text.

illustrate two microspheric specimens. The figured specimens have quite an acute peripheral margin. However, most of the specimens had a more bluntly angled, almost rounded periphery as illustrated by Gudina (1966, pl. 6, figs 4-6).

Because of the many specimens of Islandiella inflata in sample CHT 8 the assemblage is here called the Islandiella inflata assemblage, even though another species, Nonion orbiculare (Brady) is the dominant one, amounting to 35\% of the fauna.

The fauna reflects arctic but somewhat ameliorated conditions; probably milder than at present under these high latitudes. Gudina (1966, p. 21) considers Islandiella inflata as an indicator of boreo-arctic conditions, and the faunal diversity (Walton, 1964) of the assemblage is as high as 13 , with 25 different foraminiferal species present in the sample. These are high values for an area at $81^{\circ} \mathrm{N}$ latitude. For comparison, four Recent assemblages from northern East Greenland, collected by the present author at depths between $10 \mathrm{~m}$ and $30 \mathrm{~m}$, contained $4,15,16$ and 24 different species. As the present-day conditions in the area are of an interglacial character, it is highly probable that the CHT 8 assemblage also represents an interglacial.

An age estimate of this Islandiella inflata assemblage is attempted below:

Gudina (1966) described Islandiella inflata from Quaternary deposits of Northwest Siberia where it occurred in "Obskij sloi" which was considered as Holsteinian in age. It was also reported - albeit very rarely - in "Salemalskie sloi" of Saale age. In 1969 Gudina again found $I$. inflata in "Turukhanskie sloi" - also considered Holsteinian in age - in the northern Yenesey lowland, and in the same paper she also recorded it as abundant in "Kazantsevie sloi" which is considered Eemian in age. In Gudina's comprehensive paper of 1976 it is reported as common both in Eemian and Holsteinian deposits of the northern U.S.S.R.

In Baffin Island, Arctic Canada, fossil foraminiferal assemblages with many (up to $19 \%$ ) Islandiella inflata were found in the Cassidulina teretis zone (Upper Pliocene/Lowermost Pleistocene) and in the Islandiella islandica zone (Pleistocene) of Clyde Foreland (Feyling-Hanssen, 1976a) and in zone $\mathrm{G}$ (Upper Pliocene/Lowermost Pleistocene) and zones $\mathrm{F}$ and $\mathrm{D}$ (Pleistocene) of the Qivituq Peninsula (Feyling-Hanssen, 1980a). At Qivituq (Fig. 6 in Feyling-Hanssen, 1980a) Islandiella inflata is quite frequent - together with Cassidulina teretis Tappan - in zone G, is less frequent in the climatically severe zone $F$, avoids the distinctly ameliorated zone $\mathrm{E}$, and reappears - but at low numbers - in the less ameliorated zone D. Zones E and D reflect an interglacial within the Pleistocene of unknown age. But Ee-

Table 1, the Islandiella inflata assemblage:

Sample CHT 8, unit C, weight $100 \mathrm{~g}$.

\begin{tabular}{lr}
\hline Species & Percentage \\
\hline Nonion orbiculare (Brady) & 35 \\
Islandiella inflata (Gudina) & 32 \\
Elphidium hallandense Brotzen & 5 \\
Buccella frigida (Cushman) & 4 \\
Elphidium excavatum (Terquem) & 4 \\
Cassidulina reniforme Nørvang & 3 \\
Elphidium asklundi Brotzen & 3 \\
Cassidulina teretis Tappan & 2 \\
Cibicides lobatulus (Walker and Jacob) & 2 \\
Islandiella helenae Feyling-Hanssen and Buzas & 2 \\
Bucella tenerrima Bandy & 1 \\
Glabratella wrightii (Brady) & 1 \\
Islandiella islandica (Nørvang) & 1 \\
Nonionella auricula Heron-Allen and Earland & 1 \\
Elphidium albiumbilicatum (Weiss) & $<1$ \\
Elphidium frigidum Cushman & $<1$ \\
Elphidiella arctica (Parker and Jones) & $<1$ \\
Epistominella vitrea Parker & $<1$ \\
Fissurina laevigata Reuss & $<1$ \\
Guttulina glacialis (Cushman and Ozawa) & $<1$ \\
Islandiella norcrossi (Cushman) & $<1$ \\
Nonion barleeanum (Williamson) & $<1$ \\
Nonion niveumLafrenz & $<1$ \\
Oolina borealis Loeblich and Tappan & $<1$ \\
\hline
\end{tabular}

Counted 474 benthonic specimens $=1 / 4$ of the sample.

Quinqueloculina longa Gudina was observed in the uncounted part of the sample.

Number of benthonic species: 25 .

Number of specimens $/ 100 \mathrm{~g}$ sediment: 1,900 .

Faunal dominance: 35, Faunal diversity: 13.

Shallow water specimens: $45 \%$. 


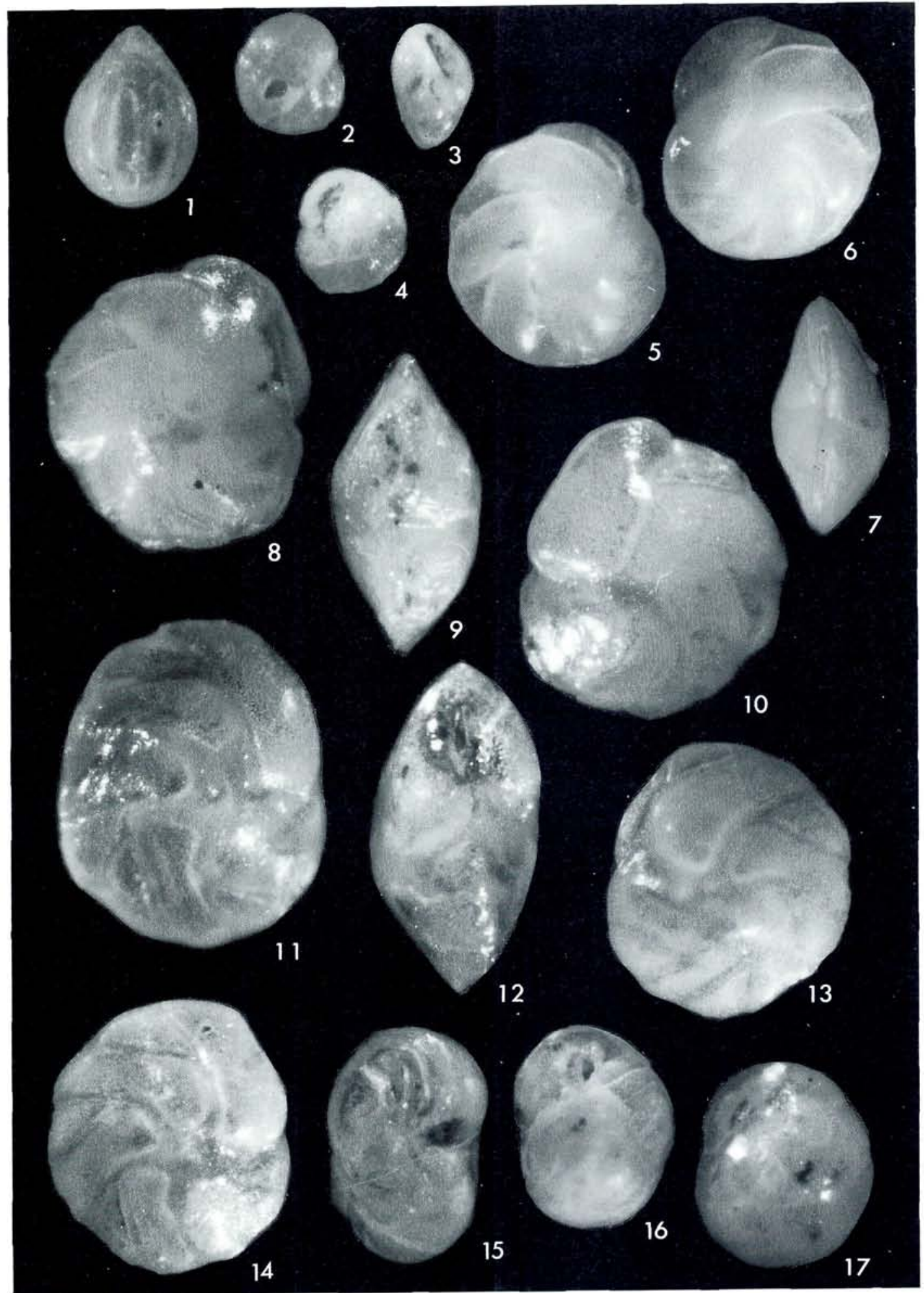

Plate $1($ All $\times 75)$.

Fig. 1. Oolina borealis Loeblich and Tappan. Specimen from sample CHT 8.

Figs 2-4. Cassidulina reniforme Nørvang. 2 and 4 , opposite sides; 3, edge view of a specimen from sample CHT 8.

Figs 5-7. Cassidulina teretis Tappan. 5, side view showing narrow apertural lip paralleling the periphery; 6 , the opposite side and 7 . edge view of a specimen from sample CHT 8.

Figs 8-14. Islandiella inflata (Gudina). 8, side view; 9, edge view; 10, other side of a specimen from sample CHT 8. 11, side view of another specimen from sample CHT 8 showing characteristically clavate chambers; 12 , edge view of the same specimen showing broad aperture and free apertural tongue. 13 and 14 , opposite sides of a third specimen from sample CHT 8.

Figs 15-17. Islandiella islandica (Nørvang). 15, edge view, showing broad aperture and apertural tongue of a specimen from sample CHT 8. 16 and 17. edge and side view of another specimen from the same sample. 


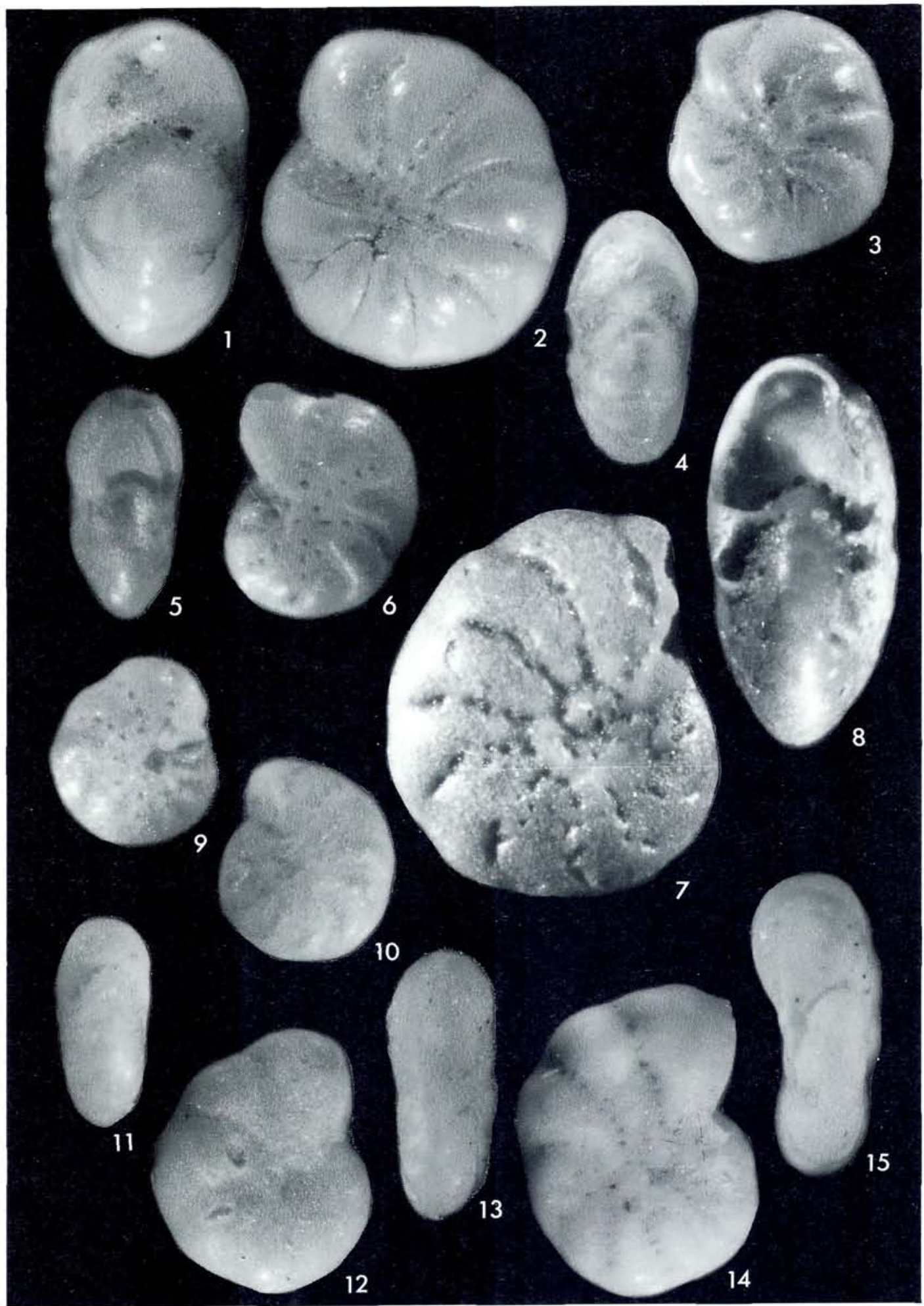

Plate $3($ All $\times 75)$

Figs 1-4. Nonion orbiculare (Brady). 1, edge view; 2 , side view of a specimen from sample CHT $8 ; 3$, side view; 4, edge view of another specimen from sample CHT 8.

Figs 5-6. Elphidium albiumbilicatum (Weiss). 5, edge view showing foramen of the penultimate septum; 6, side view showing tapering sutural fields of a specimen from sample CHT 13.

Figs 7-8. Elphidium asklundi Brotzen. 7, side view; 8, edge of a worn specimen from sample CHT 13.

Figs 9-11. Elphidium excavatum (Terquem), 9, side view of a specimen from sample CHT 8, 10, side view and 11, edge view of another specimen from the same sample.

Figs 12-15. Elphidium hallandense Brotzen (= Elphidium subarcticum Cushman). 12 and 13, side and edge view of a specimen from sample CHT 13, 14, side view and 15, edge view of a specimen from sample CHT 8. 
Table 2, the Elphidium hallandense assemblage. Sample CHT 13, unit D, weight $100 \mathrm{~g}$.

\begin{tabular}{lc}
\hline Species & Percentage \\
\hline Elphidium hallandense Brotzen & 45 \\
Nonion orbiculare (Brady) & 30 \\
Elphidium albiumbilicatum (Weiss) & 14 \\
Buccella frigida (Cushman) & 5 \\
Elphidium asklundi Brotzen & 2 \\
Glabratella wrightii (Brady) & 2 \\
Elphidium frigidum Cushman & 1 \\
Elphidium incertum Cushman & 1 \\
Islandiella inflata (Gudina) & 1 \\
Cassidulina reniforme Nørvang & $<1$ \\
Cibicides lobatulus (Walker and Jacob) & $<1$ \\
Elphidiella arctica (Parker and Jones) & $<1$ \\
Islandiella islandica (Nørvang) & $<1$ \\
\hline
\end{tabular}

Counted 332 specimens $=5 / 36$ of the sample.

Guttulina glacialis (Cushman and Ozawa) and one reworked Cibicides grossa Ten Dam and Reinold occurred in the uncounted part.

Number of benthonic species: 14 .

Number of specimens $/ 100 \mathrm{~g}$ sediment: 2,400 .

Faunal dominance: 45 , Faunal diversity: 5 .

Shallow water specimens: $92 \%$.

mian has been suggested (Feyling-Hanssen and Ulleberg, 1984). Islandiella inflata is absent in the youngest part of the sequence at Qivituq. At Pigojoat also on the northeast coast of Baffin Island (Feyling-Hanssen, 1980b; 1985) I. inflata accounted for $3 \%$ of an assemblage probably correlatable with zone $\mathrm{D}$ of Qivituq. The closest correlation is found between the present assemblage of sample CHT 8, and an assamblage from a sample (08087601) collected $12 \mathrm{~m}$ above sea level in the settlement of Broughton Village, south of Qivituq Peninsula, Baffin Island. Islandiella inflata comprised $21 \%$ of that assemblage, and was the dominant species (cf. Feyling-Hanssen, 1985, p.382 and 384). Again, that assemblage shows affinity to assemblages from Cape Broughton, on the northern tip of the island (Sample nos 11087404 and 11087405, FeylingHanssen 1976b, p. 165). The Cape Broughton deposits were originally (Feyling-Hanssen, 1976b) thought to be of Mid Wisconsin (MidWeichsel) interstadial age, but later (FeylingHanssen, 1980a, 1985) considered as Pre Wiscon$\sin$ in age. They were dated by radiocarbon at $>40,000$ B.P. and later Miller (1985, p. 420$)$ published an amino-acid-derived age of 210,000 years for the Cape Broughton deposits.

Foraminiferal species similar to Islandiella inflata, e.g. Islandiella limbata (Cushman and
Hughes), have been described from the Pliocene and Lower Pleistocene of California (e.g. Galloway and Wissler, 1927), from Plio/Pleistocene deposits of Amchitka Island, Alaska (Cushman and Todd, 1947) and from Miocene and Pliocene of Sakhalin (Voloshinova, Kusnetsova, Leonjenko, 1970). On ther other hand, I. inflata has been recorded from Holocene deposits of the western Barents Sea (Lorange, 1977; Østby and Nagy, 1982).

The Islandiella inflata assemblage (sample CHT 8) of the Ymer Formation could, therefore, be anything in age from Upper Pliocene to Upper Pleistocene. However, the co-occurrence of $I$. inflata with a few Cassidulina teretis in this assemblage may preclude an uppermost Pleistocene age, whereas the absence of characteristic Lower Pleistocene shallow water species such as Elphidiella hannai Cushman and Grant and $E$. rolfi Gudina and Palovova from the zone precludes a Lower Pleistocene age (cf. FeylingHanssen, 1986). The deposit belongs to an interglacial, and on the basis of its foraminifera and undependent dating results a Holsteinian age is suggested rather than an Eemian.

\section{The assemblage of sample CHT 13}

The results are presented in Table 2.

Islandiella inflata is also present in this assemblage, albeit in low numbers (1\%). The dominant species is Elphidium hallandense Brotzen $(=E$. subarcticum Cushman) (45\%) followed by Nonion orbiculare $(30 \%)$ and Elphidium albiumbilicatum (Weiss) $(14 \%)$. They are all shallow water species. E. hallandense is arctic in habitat, $N$. orbiculare also occurs in less severe environments, whereas $E$. albiumbilicatum seems to be boreo-arctic. The latter also indicates reduced salinity for instance as might be caused by an influx of glacial meltwater, which could easily have affected the benthos at such shallow waters as are indicated by this assemblage. Pronounced shallow-water specimens account for $92 \%$ of the fauna, and the waterdepth during its deposition might have been $10 \mathrm{~m}$ or less.

The age of this unit is most probably approximately the same as for the Islandiella inflata assemblage. 
Acknowledgements - I want to thank W. Austin who critically read the manuscript of this paper, and corrected the English of the text, S. Aa. Meldgaard who processed the samples and made the photographs for the plates, and L. $\varnothing$. Mogensen who arranged and typed the manuscript.

\section{References}

Cushman, J. A. and Todd, R. 1947: A foraminiferal fauna from Amchitka Island, Alaska. Contributions from the Cushman Laboratory for Foraminiferal Research, 23, pt 3, 60-72.

Feyling-Hanssen, R. W. 1976a: The Clyde Foreland Formation, a micropaleontological study of Quaternary stratigraphy. 1st. Int. Symp. on Benthonic Foraminifera of Continental Margins, Pt.b: Paleoecology and Biostratigraphy. Maritime Sediments, Spec. Pub. 1, 315-377.

Feyling-Hanssen, R. W. 1976b: A Mid-Wisconsinian interstadial on Broughton Island, Arctic Canada, and its foraminifera. Arctic and Alpine Res. 8, 2, 161-182.

Feyling-Hanssen, R. W. 1980a: Microbiostratigraphy of young Cenozoic marine deposits of the Qivituq Peninsula, Baffin Island. Marine Micropaleontology 5, 153-184.

Feyling-Hanssen, R. W. 1980b: An assemblage of Pleistocene foraminifera from Pigojoat, Baffin Island. Jour. Foram. Res. 10, 266-285.

Feyling-Hanssen, R. W. 1983: Quantitative methods in micropaleontology. In Costa, L. I. (ed.): Palynology-Micropalacontology: Laboratories, Equipment and Methods, 109128. NPD-Bulletin 2, Oljedirektoratet, Stavanger.

Feyling-Hanssen, R. W. 1985: Late Cenozoic marine deposits of East Baffin Island and East Greenland, microbiostratigraphy-correlation-age. $I n \mathrm{~J}$. T. Andrews (ed.): Quaternary Environments: Eastern Canadian Arctic, Baffin Bay, and West Greenland. Allen and Unwin, 354-393.

Feyling-Hanssen, R. W. 1986: Grænsen mellem Tertiær og Kvartær i Nordsøen og i Arktis, fastlagt og korreleret ved hjælp af benthoniske foraminiferer. Dansk geologisk Forening, Ársskrift for 1985, 19-33.

Fyling-Hanssen, R. W. and Ulleberg, K. 1984: A Tertiary-
Quaternary section at Sarsbukta, Spitsbergen, Svalbard, and its foraminifera. Polar Research 2 n.s., 77-106.

Galloway, J. J. and Wissler, S. G. 1927: Pleistocene Foraminifera from the Lomita Quarry, Palos Verdes Hills, California. Joun. Paleontology 1, 35-87.

Gudina, V. I. 1966: Foraminifera and stratigraphy of the Northwest Siberian Quaternary. Akad. Nauk SSSR, Siberian dept., Inst. Geol. and Geoph. U.D.K.563.12 (119) (571.1). $132 \mathrm{pp}$.

Gudina, V. I. 1969: The marine Pleistocene of Siberian lowlands. Foraminifera of the north part of Yenisei's lowlands. Acad. nauk SSSR, Siberian dept. Institute of Geology and Geophysics 63, 1-80.

Gudina, V. I. 1976: Foraminifera, stratigraphy, and paleozoogeography of the marine Pleistocene of the northern U.S.S.R. Akad. Nauk SSSR, Siberian Branch, Trud. Inst. Geol. Geoph. 314, 126 pp.

Hjort, C. 1981: Quaternary geology in northeasternmost Greenland, 114-115 in: Schytt, V. Boström, K. and Hjort, C.: Geoscience during the Ymer- 80 expedition to the Arctic. Geol. Fören. Stockholm Förh. 103, 109-119.

Hjort, C. and Feyling- Hanssen, R. W. 1987: The Ymer-Formation - an interglacial sequence in northeasternmost Greenland. Polar Research 5 n.s., 347-350.

Lorange, K. 1977: En mikropaleontologisk-stratigrafisk undersøkelse av kvartare sedimenter $i$ nordvestre del av Barentshavet. Thesis, Geological Institute, University of Oslo, 1-237.

Miller, G. H. 1985: Aminostratigraphy of Baffin Island shellbearing deposits. In J. T. Andrews (ed.): Quaternary Environments: Eastern Canadian Arctic, Baffin Bay and Western Greenland. Allen and Unwin, 394-427B.

Voloshinova, N. A., Kusnetsova, V. N., Leonjenko, L. S. 1970: Foraminifera in the Neogene of Sakhalin. "Nedra", Leningrad 284, 1-303.

Walton, W. R. 1964: Recent foraminiferal ecology and paleoecology, 151-237 in Imbrie, J. and Newell, N. D. (eds.): Approaches to Paleoecology. Wiley and Sons, New York.

Østby, K. L. and Nagy, J. 1982: Foraminiferal distribution in the western Barents Sea, Recent and Quaternary. Polar Research 1, 53-95. 